\title{
Exploring Culture in Texts Designed for Use in Adult ESL Classrooms
}

Roumiana Ilieva

\begin{abstract}
This article examines the presentation of culture in texts designed for adult learners of English as a second language in Canada. Guiding the analysis is a view of culture as a process of making sense of the world and a site of struggles of people with multiple and shifting identities over meaning and representation. The article discusses the role of texts as culture bearers in second language classrooms. It also addresses aspects of the method of critical discourse analysis, which is employed to tackle the following questions: What is considered cultural knowledge in the selected texts? Whose views of culture are presented in the texts? Do these texts allow students to explore and negotiate their own cultural experiences in the new Canadian environment? The article concludes that in the selected texts culture is constructed as a national attribute consisting of sets of stable values and behavior patterns, a construction that ignores the conflicts and fluidity of cultural forms that characterize human encounters.
\end{abstract}

\section{Introduction}

The aim of this article is to examine how culture is presented in texts designed for adult learners of English as a second language in Canada. My interest in this topic stems from the dissatisfaction with classroom materials and practices of adult immigrants who have shared with me that the way culture is addressed in their classroom ESL learning experiences does not reflect their own immigrant experiences. ${ }^{1}$ I focus on excerpts from the textbook Canadian Concepts 3 (Berish \& Thibaudeau, 1992a) and will try to answer the following questions: What is considered cultural knowledge in these texts? Whose views of culture are presented in the texts? Do these texts allow students to explore and negotiate their own cultural experiences in the new Canadian environment? ${ }^{2}$

Apart from one volume of 24 articles describing various aspects of second language materials prepared in Canada (Podoliak, 1988), there has been no consistent effort to examine existing Canadian texts designed for use by adult learners of English. However, research on the kinds of information presented to learners through study materials on the Canadian way of life seems an important area of inquiry at a time when it is maintained that cultural content has been transformed from "an add-on to an integral part" (Courchêne, 1996, p. 1) of the second language classroom. This article is just an initial step in the direction of analyzing constructions of culture in Cana- 
dian textbooks for adult learners of English. I outline at the outset of the article the conceptualizations of culture that guide me in this project. Next I explore briefly the role of texts and textbooks as culture bearers in second language classrooms as well as aspects of the method of critical discourse analysis that I find useful for investigating the data. I then engage in a critical discourse analysis of the selected texts and draw conclusions about the presentation of culture in them.

\section{What is Culture?}

The discipline of cultural anthropology offers insights into the nature of culture that could be productive for the conceptualization of culture in language teaching. Early developments in anthropological theory lead to conceptualizations of culture as a stable core set of values, beliefs, customs, and behaviors (Kroeber \& Kluckhohn, 1952). However, in the second half of this century there was a shift in conceptualizations of culture to include meanings, symbols, and language-a shift particularly well expressed in Geertz' (1973) definition of culture as "the fabric of meaning in terms of which human beings interpret their experience and guide their actions" ( $p$. 145). Since the 1960s Marxist anthropologists have insisted on power inequality and conflict as an inherent part of human culture, and in the last three decades, especially with the advent of postmodernism, there has been an urge in cultural anthropology to construe cultural meanings and symbols as inherently a matter of political and economic interests (Baumann, 1996; Clifford, 1988; Keesing, 1994; Marcus \& Fischer, 1986). As Fiske (Kramsch, 1993a) argues,

Culture is not a relatively harmonious and stable pool of significations, but a confrontation between groups occupying different, sometimes opposing positions in the map of social relations, and the process of making meanings (which is, after all, the process of culture) is a social struggle, as different groups struggle to establish meanings that serve their interests. (p. 24)

Thus culture is not "an object to be described ... [nor] a unified corpus of symbols and meanings that can be definitely interpreted; [it] is contested, temporal, and emergent" (Clifford, 1986, p. 19); it has an essentially changing character and process nature (Street, 1993) and is characterized as much by multivocality, diversity, conflicts, and contradictions as by consistency (Rosaldo, 1993). As Rosaldo points out, however, the conflicts, contradictions, and struggles arise not only at "the boundaries of officially recognized cultural units, but also at less formal intersections, such as those of gender, age, status, and distinctive life experiences" (p. 29). In other words, Rosaldo is critical of a conceptualization of culture in ethnic terms. Contrasting con- 
temporary views of culture with more traditional views of culture as a national attribute, he suggests that

In contrast with the classic view, which posits culture as a self-contained whole made up of coherent patterns, culture can arguably be conceived as a more porous array of intersections where distinct processes crisscross from within and beyond boundaries. Such heterogeneous processes often derive from differences of age, gender, class, race, and sexual orientation. (p. 20)

In the field of curriculum theorizing, McCarthy (1998) also critiques the current ethnicization of culture, arguing that education should not treat culture "through a narrow ethnic lens" (p. 148) because in everyday human encounters cultural forms release multiple effects across the divides of nation. ${ }^{3}$

Although the limitations of ethnicization of culture have not yet been made explicit in conceptualizations of culture among language education theorists interested in the topic, the significance of human agency, struggle, and conflict in determining cultural forms has been acknowledged in the works of Atkinson (1999), Duff and Uchida (1997), Kramsch (1993a, 1993b), and Pennycook (1995) among others. Kramsch (1993a), for example, argues that in the context of language teaching and learning, culture is conflict and a "struggle between the learners' meanings and those of the native speakers" (p. 24) and insists that language classrooms should offer space for students to experience "the back-and-forth of cultural border crossings" (1993b, p. 356). Building on these current conceptualizations of the notion of culture in cultural anthropology and language education, the analysis presented below is guided by a view of culture as a process of making sense of the world and a site of social differences and struggles over meaning and representation of people with multiple and shifting identities. ${ }^{4}$ In other words, the focus is on the extent to which texts designed for use by adult learners of English acknowledge the heterogeneity and fluidity of cultural forms as experienced by a variety of members of a cultural group in a variety of situations.

\section{The Place of Culture in Textbook Materials}

Research in cultural instruction in language education suggests that textbooks are an influential bearer of culture in the second language classroom (Damen, 1987), functioning to purvey images of the new culture (Byram, 1989; Cortazzi \& Jin, 1999). Hutchinson and Torres (1994) claim that, despite the impact of study materials as "an almost universal element" (p. 315) of English language teaching, textbooks have received little attention from researchers. In addition, Grady (1997) suggests that "a critical perspective on what knowledge is legitimated in ... texts ... has been slow to emerge in the field of teaching English as a second language" (p. 7). To assess the cultural 
knowledge legitimated in second language classroom contexts, it is imperative that we focus on the texts used in these classrooms. As Duff and Uchida (1997) point out, texts provide "a focal point and medium" for teachers' and students' negotiations with aspects of the target culture and their own "(dis)identification with certain representations" (p. 470). In the context of adult ESL classes in Canada, students are confronted with portrayals of Canadian culture through course materials, and they must react to them by "positioning themselves and articulating their own sociocultural (dis)identification with the characters and themes" (p. 471). Such arguments are obviously based on the assumption that curriculum content matters because it helps shape the ways students come to understand themselves and their world, and the ways they can act in it and on it (Manicom, 1987). Of course, although particular texts cannot be equated with curriculum, they often shape practice and reflect curricular orientation because more often than not teachers rely on them to organize and structure students' learning experiences. Indeed, textbooks are regarded as authoritative, accurate, and necessary (Cortazzi \& Jin, 1999; Kramsch, 1988) and normative in presenting "cultural information as it should be viewed and interpreted" (Kramsch, 1988, p. 66). At the same time, textbooks are constructs that represent the way authors (and publishers) conceive of language, culture, and learning, and the way they construe for instructional purposes an integrated world of the new for the students' reality. Textbooks thus legitimize selective forms of knowledge and culture (Apple, 1990) and are ideological constructions. "They help set the canons of truthfulness and, as such, also help recreate a major reference point for what knowledge, culture, belief, and morality really are" (p. 20).

Of course, given teachers' and students' agency in mediating and transforming textual material employed in the classroom through their positioned interpretations and reinterpretations of educational processes and tools ( $p$. 20), we cannot assume that what is in the text is actually taught or learned. Thus one cannot determine the meanings in a text by a straightforward encounter with the text itself because readers do not passively receive texts, but actually read them on the basis of their own classed, raced, and gendered cultural experiences. ${ }^{6}$ As the meaning of a text cannot be claimed to be intrinsic to it, a text analysis can only attempt to examine the perspectives that appear to be in the text. An analysis solely of curriculum materials can address only "the possibilities of meanings which may have entered into the production of the materials, and the possibilities of meaning which may be constructed in the intended use of these materials" (Manicom, 1987, p. 78). In the pages that follow I present such an analysis fully aware that people can potentially respond to a text in dominated, negotiated, or oppositional ways (Apple, 1990). Despite the variabilities in readers' responses to a curriculum text, "whose knowledge it is that students are learning, negotiating, or op- 
posing and what the social/cultural roots and effects are of such processes" (p. 30) seem, in my opinion, important issues.

\section{Critical Discourse Analysis}

The method employed in the next section to unpack the constructions of culture in the selected texts designed for use in adult ESL classrooms in Canada is critical discourse analysis. Critical discourse analysis stems from a view of language use as a form of social practice. More specifically, "critical discourse research is centrally concerned with the way language is implicated in the reproduction of and resistance to inequitable relations of power in educational settings" (Norton, 1997, p. 207). Thus, as Kress (1990) points out, critical discourse analysts focus on texts and their contexts with the intention "to show the imbrication of linguistic-discursive practices with the wider sociopolitical structures of power and domination" (cited in Pennycook, 1994, p. 122).

Most recently, discourse-based studies in education have been influenced by Foucault's $(1972,1980)$ poststructuralist analyses of the constructing character of discourse in human history and culture (Luke, 1995; Norton, 1997). As Luke points out, Foucault's work offers educators a fundamental shift in the way they can view educational texts and discourses, a shift from a focus "on text and discourse as constructed artifact explicable by reference to essential characteristics of its producers and productive contexts to the study of how texts are constructive of social formations, communities, and individuals' social identities" (p. 9, italics added). Thus from a Foucauldian perspective a critical discourse analysis would involve not an analysis of how texts reflect reality, but how the discourses operating in them produce reality. For example, Talbot (1992), a critical discourse analyst who perceives a text as a "tissue of voices," is interested in the identities an author sets up for himself or herself and for his or her readers in different segments of a text. Another critical discourse analyst, Kress (1989), approaches texts with the following questions in mind: why and how is a topic being written about, and what other ways of writing about the topic are there?

A useful model of critical discourse analysis, which allows multiple points of entry into text analysis, is provided by Fairclough $(1989,1995)$. Fairclough argues that three interrelated processes of analysis, tied to three interrelated dimensions of discourse, should be undertaken when analyzing a given text critically. He maintains that texts are embedded in discourse practices, which in turn are embedded in sociocultural practices. Consequently, a critical discourse analysis should entail a description of the linguistic features of a text (text analysis), an interpretation of the processes of production and interpretation of the text (processing analysis), and an explanation of the conditions of the production and interpretation of the text (social analysis). 
As textbooks are viewed by critical discourse analysts as an educational genre, which entails an interconnectedness of the features of the genre with the features of the social occasions in which they are employed (Kress, 1989), a critical discourse analysis of the texts could provide rich information on the authors' perceptions of their audience as well as on their views as to what language and cultural instruction to adults should look like. Moreover, as culture is a site of power struggles, a critical discourse analysis of the constructions of culture in the selected texts seems a useful tool in searching for answers to the questions posed at the beginning of this article. In the context of this inquiry such analysis would attend to the cultural discourses evident in the selected texts and the linguistic features that suggest the presence of these discourses as well as attempt to address wider sociocultural practices within which textbook production is embedded.

\section{Culture in Texts Designed for ESL Adults}

The texts, which are analyzed from a critical discourse perspective in this section, are excerpts from a unit entitled "Department Stores" in the textbook Canadian Concepts 3 (Berish \& Thibaudeau, 1992a). These texts are chosen for several reasons. The theme, shopping, seems to be considered important for a number of writers for adult learners of English who include units on this subject in their texts (Employment and Immigration Canada, 1991; Engkent \& Bardy, 1992). Moreover, given that I myself am an adult immigrant to Canada, I have experienced shopping as a major activity in the lives of many Canadians. More important, what shopping has meant in my experiences in my native country differs markedly from the understandings of shopping I have had to negotiate since my arrival in Canada. Finally, I feel that a critical discourse analysis of texts on this topic, texts that allow me to catch a glimpse of what textbook writers (and publishers) might deem important to communicate to adult immigrants like myself on a practice I have experienced as distinctly foreign, could provide a preliminary case for testing the usefulness of this methodological approach for analyzing constructions of culture in a larger segment of texts designed for adult learners of English.

The textbook Canadian Concepts 3 is the third in a six-book series designed for "students learning English in Canada" (Berish \& Thibaudeau, 1992a, p. $v)$. The authors do not provide more detailed information about the intended audience of the series, but state that "survival topics and cultural information based on Canadian themes help students integrate into the community" (p. $v)$. Thus the focus of the units is survival topics and general cultural information. The aim of the series is to provide students with "challenging input" (p. v) and involve them in "information exchange" (p. v) and activities that develop their fluency and allow them to gain confidence and motivation to function in English. Each unit in the book is made up of a variety of activities that follow a three-part pattern. The first section introduces the topic through 
"Get Ready" activities aimed to generate students' interest with prediction exercises, discussion questions, and so forth. The next section calls for students to work with material on the topic in a core reading or listening activity to develop skills for reading and listening for general ideas and detailed information. In the third section the language is recycled through a variety of exercises like vocabulary and grammar review, discussion, and writing activities. The excerpts chosen represent the two core readings for "cultural information" (p. 91) included in the unit, a multiple-choice task students are to engage in to prepare for a listening activity on the topic, and the questions for a group discussion of the topic offered as a concluding activity in the unit. ${ }^{8}$ I offer below a brief critical discourse analysis of each of these texts, ${ }^{9}$ then I make concluding remarks on what image of one aspect of Canadian culture this unit purveys.

The first text, entitled "Department Stores in Canada" (p. 94), presents information on the history of shopping in Canada and how department stores came into being. The Teacher's Manual suggests that the text is intended to assist students in developing reading skills (Berish \& Thibaudeau, 1992b). Although the authors have not pointed to specific goals for cultural instruction with this or other texts in the textbook, the fact that they have designated it "a cultural information text" implies that they intend it to purvey an image of the history of department stores in Canada, which is suggested as the main idea of the text in the Teacher's Manual. A critical discourse analysis of the text would involve an analysis of the discourses embedded in the text, which in turn are viewed to produce the reality of the sociocultural practices presented in the text. The text seems designed for an audience that is assumed to find the presented information interesting and useful. Through the absences evident in the text, the reality it constructs for its readers points to the presence of colonial, capitalist, and urban discourses. For example, although the authors start their story with the establishment of trading posts in Canada, nowhere in the text are the trading practices of an important section of Canadian population, First Nations, addressed. Neither is it made explicit that department stores are primarily part of an urban culture. Moreover, the historical view presented makes the advent of department stores inevitable, thus hiding the capitalist discourse embedded in the text. Department stores are presented as the best shopping institution that has come into existence because they offer a variety of goods and moneyback guarantees to customers. The text portrays department stores as inanimate agents and makes no reference to the real agents who establish them, that is, capitalist entrepreneurs who have the financial means to do so. In terms of the language used to denote customers in trading posts, general and department stores, the repeated use of people points to a generalized notion of Canadians as a unitary group. The questions that follow this text ask for answers that would simply involve students in "citing" (de Castell, 
1990) the text and, in my opinion, would in no way help them integrate into the new Canadian environment. Although it might be naïve to assume that the particular absences pointing to specific discourses that I was able to discern in my interaction with the text are those that other readers would note, it is important to mention that it would have been useful if the authors had stated explicitly that they were presenting only one version of the history of department stores in Canada. In addition, they could have included questions following the text that point to the existence of other understandings of this process. An example would be a question like "Do you think everybody is happy with the establishment of department stores in Canada?"

The second excerpt, entitled "Pay at the Cash" (Berish \& Thibaudeau, $1992 a$, p. 95), consists of a multiple-choice task that is intended to help students prepare for listening to a dialogue involving interaction in a department store. The task is limiting because it leads students to construct from an unrealistic, unified cultural point of view what is "adequate" behavior in a department store. One of the questions, which refers to what would be considered the behavior of a thief in a department store, is particularly controversial in the answer it suggests. ${ }^{10}$ Another of the questions, which suggests the option of paying for something with a credit card, is a clear example of capitalist discourse as it refers to a shopping habit that by no means reflects the reality of shopping for many poor people who simply cannot apply for credit cards because of their financial situation. Again, it would be naïve to charge the authors for this particular omission because clearly other readers will find other omissions. Rather, the point I wish to reiterate is that a more self-reflective position on the part of the authors that they represent only mainstream experiences with department store shopping would have greatly enhanced the possibilities for negotiating the answers to the multiple-choice task they suggest.

The third text, entitled "Buying on Sale" (p. 97), describes "the different times when you can buy things on sale in Canada" (Berish \& Thibaudeau, 1992 b, p. 84) and reflects class, consumer-education, and paternalistic discourses. The text assumes that the information presented will be of use to new Canadians who may be unfamiliar with the notion of buying on sale. The class discourse can be traced to the assumption evident in the text that "all" Canadians have a disposable income that allows them to shop in this way. The discourse of consumer education is evident in the detailed explanation of what "looking for bargains" means and blends with paternalistic discourse in the last two paragraphs of the text, which through the use of imperatives consider the text's readers as novice shoppers lacking the knowledge to be "smart" shoppers. Capitalist discourse is again present in the portrayal of stores as agents, a construction that hides the material effects 
brought by actual people in power positions who make the decisions about sales.

The last excerpt, entitled "What About You?" suggests questions for students to discuss in a group, presumably in an attempt to allow students to present their own opinions on the topic. Interestingly enough, many questions are constructed as yes/no questions or require short answers, for example, "Are there large department stores in most countries? Do you line up at the cash to pay in all countries? Are things more expensive in department stores or in small stores in other countries?" (Berish \& Thibaudeau, 1992a, p. $100)$. In this respect they do not allow much depth in probing in students' experiences. More important, although there is limited room for students to compare and contrast the shopping practices and activities at work in Canada and in their own countries, the questions assume a universality of cultural experiences around shopping in Canada as well as in a student's native country. Thus these questions can only act to silence some students whose shopping experiences may not conform to mainstream expectations. Some possible questions that could have been more welcoming to students are: "Tell your group about your shopping experiences in Canada and in your country. Do you think that all Canadians can pay by credit card in a department store? Why?"

In summary, I believe that the image of one aspect of Canadian culture, shopping, which these texts purvey could be interpreted as follows. For the authors of this textbook shopping is an important part of Canadian life or culture; it takes place primarily in big department stores where buying on sale and looking for bargains is good. I draw this conclusion essentially because the topic is given space in the textbook, but also because the discourse about shopping presented is positive and consensual; nothing is said about shopping at other times than sales, shopping from stores like Value Village or the Salvation Army, as well as the impossibility for some poor people to shop for clothes or furniture. The texts lead me to believe that for the authors cultural knowledge is knowledge of unquestioned cultural "facts" and discrete sets of behaviors. Such a view is in line with mainstream approaches to cultural instruction in language teaching that operate on the assumption that culture can be taught and learned via imparting information (Kramsch, 1993a, Pennycook, 1995). The assumption here seems to be that if students know how department stores developed or what "advantages" they offer (compared with smaller stores) as well as when to shop for coats or bathing suits, they have learned something about integrating into Canadian society. Moreover, Canadians seem to be referred to as a generalized national group who usually shop when there are sales. For example, the value of "looking for bargains" is not presented as limited to people who can afford the time to look for bargains as well as the money to shop. Finally, the texts in no way engage learners to explore their own experiences with shopping in 
Canada, nor do they allow them to deal with the conflicts (compare Kramsch, 1993a) that students may have experienced in struggling with new meanings of "to shop" they have to learn (or choose not to learn, or most probably relate to in contradictory ways at different times and in different contexts) in Canada. For such exploration to take place in the classroom, the texts need to be deconstructed and more open-ended questions discussed.

It is unfair to hold the authors of the texts solely responsible for the portrayal of shopping in the unit. They are themselves embedded in the discursive and sociocultural practices of the market-driven textbook publishing industry and the economic and political constraints of its resources and power (Luke, 1988). Moreover, it is not students or even teachers that textbook publishers (and perhaps authors) perceive as the consumers of their products, but rather decision-makers who purchase books on behalf of students and instructional settings (Lorimer, 1984). Indeed, as textbooks are an intersection point of curriculum, commerce, and culture (Venezky, 1992), they are complex entities, and any analysis of their content should take into account the conditions of their production and use. With respect to their use, for example, the source of the "authority" of textbooks has been a matter of controversy for some time now (de Castell, Luke, \& Luke, 1989). It is clear that although students interact directly with the text, what they acquire from it is mediated by the instructional practices they engage in with the teacher and their peers in the classroom. Nevertheless, the literature on how textbooks are employed in classrooms more often than not points to their use for mastery of content rather than deconstruction of the meaning of the text (Doyle, 1992).

As the analysis presented above focuses solely on what possibilities for the meanings of the selected texts could be discerned in the texts themselves, it is obvious that the use of these texts in the classroom would add indispensable dimensions to this analysis. Although this will be the focus of future work, it is important to reiterate at this stage that although teachers and students may accept, negotiate or resist the representations of a topic in a text, the effects of this process are of paramount significance for what students learn. Given the importance of texts as cultural artifacts and authoritative tools that tend to represent dominant ideas in classrooms it is imperative to note that:

The circle of dominant ideas does accumulate the symbolic power to map or classify the world for others; its classifications do acquire not only the constraining power of dominance over other modes of thought but also the initial authority of habit and instinct. It becomes the horizon of the taken-for granted: what the world is and how it works, for all practical purposes. (Hall, 1988, p. 44) 


\section{Conclusion}

This study employed a critical discourse analysis in an attempt to answer the following research questions: What is considered cultural knowledge in some texts designed for adult ESL students? Whose views of culture are presented in the texts? Do these texts allow students to explore and negotiate their own cultural experiences in the new Canadian environment? The conclusions drawn from the critical discourse analysis of the selected texts suggest that the authors of Canadian Concepts 3 (Berish \& Thimaudaau, 1992a, $1992 \mathrm{~b}$ ) seem to hold a mainstream understanding of the concept of culture in second language instruction, that is, culture is constructed as a national attribute consisting of sets of stable values and behavior patterns. The approach to culture evident in the texts demands that students absorb a number of unquestioned and uninterpreted "facts" that throw little light on what shopping means for different groups of Canadians in a variety of contexts. The view of culture dominating the texts is the authors' (and publishers') view, which in this particular unit seems tied to middle-class shopping habits and values. As the topic is presented through the authoritative voice of an imaginary classless, ageless, genderless "expert" in shopping in Canada, it seems to alienate students rather than assisting them to integrate into Canadian society. ${ }^{11}$ Although I am aware that impersonality, "objectivity," and truth claims are features characteristic of the textbook genre (de Castell, 1990; Kress, 1989), I believe that it is time that textbook writers interested in assisting adult learners of English in their integration into Canadian society presented less unitary portrayals of Canadian society in their texts. More important, I maintain that texts should allow students to negotiate their place in the new (for them) Canadian culture(s) by addressing the conflicts and fluidity of cultural forms that are an inherent part of everyday human encounters.

\footnotetext{
Notes

${ }^{1}$ See Norton (1995b) for a similar observation.

${ }^{2}$ I consider it important to address these particular questions on the basis of a study I conducted on the place of culture in second language education (Ilieva, 1997).

${ }^{3}$ Recent publications by critical theorists also suggest a more complex understanding of culture (Freire \& Macedo, 1995).

${ }^{4}$ See Norton (1995a) for an elaborate discussion of the notion of identity.

${ }^{5}$ See, for example, Morgan (1997) for a reflexive use of textbook material with a view to increasing the emancipatory potential of classroom activities for adult learners of ESL.

${ }^{6}$ Canagarajah (1993), for example, explores the complexity and the interconnection between domination and resistance that students experience when negotiating textbook material.

${ }^{7}$ Similar questions guide me later in the analysis of the selected texts.

${ }^{8}$ One cannot assume that these texts could be representative of the variety of texts on shopping available in Canadian textbooks for adult learners of English. Nevertheless, given that these are
} 
included in a series that went through a second edition in 1997, it could be argued that there is a market for such texts.

${ }^{9}$ I understand text to be a piece of written or spoken language (Fairclough, 1995).

${ }^{10 .}$ People think you want to steal things if you walk around with them" (Berish \& Thibaudeau, 1992a, p. 95).

${ }^{11}$ In my opinion, students would have a greater opportunity to identify with the texts if the points of view of a variety of classed and gendered immigrants who relate their experiences with department stores and sales in Canada were presented.

\section{Acknowledgments}

The research reported here is supported by a SSHRC doctoral fellowship. I would like to thank Kelleen Toohey and Patrick Mathews for their support and encouragement and the three anonymous reviewers for their constructive comments and suggestions.

\section{The Author}

Roumiana Ilieva is a doctoral candidate at the Faculty of Education, Simon Fraser University and a recent immigrant to Canada. She has taught adult EFL in Bulgaria and ESL at Mosaic, Vancouver. Her research interests include cultural instruction in adult ESL education, sociocultural, poststructural, and critical perspectives to language learning, and the integration of immigrants into educational settings.

\section{References}

Apple, M. (1990). The text and cultural politics. Journal of Educational Thought, 24(3A), 17-33

Atkinson, D. (1999). TESOL and culture. TESOL Quarterly, 33, 625-654

Baumann, G. (1996). Contesting culture. Discourses of identity in multi-ethnic London. Cambridge, MA: Cambridge University Press.

Berish, L., \& Thibaudeau, S. (1992a). Canadian concepts 3. Scarborough, ON: Prentice-Hall.

Berish, L., \& Thibaudeau, S. (1992b). Canadian concepts 3: Teacher's manual. Scarborough, ON: Prentice-Hall.

Byram, M. (1989). Cultural studies in foreign language education. Clevedon, UK: Multilingual Matters.

Canagarajah, A.S. (1993). Critical ethnography of a Sri Lankan classroom: Ambiguities in student opposition to reproduction through ESOL. TESOL Quarterly, 27, 602-626

Clifford, J. (1986). Introduction: Partial truths. In J. Clifford \& G. Marcus (Eds.), Writing culture: The poetics and politics of ethnography (pp. 1-26). Berkeley, CA: University of California Press.

Clifford, J. (1988). The predicament of culture. Cambridge, MA: Harvard University Press.

Cortazzi, M., \& Jin, L. (1999). Cultural mirrors: Materials and methods in the EFL classroom. In E. Hinkel (Ed.), Culture in second language teaching and learning (pp. 196-219). Cambridge, MA: Cambridge University Press.

Courchêne, R. (1996). Teaching Canadian culture: Teacher preparation. TESL Canada Journal, $13(2), 1-16$.

Damen, L. (1987). Culture learning: The fifth dimension in the language classroom. Reading, MA: Addison-Wesley.

de Castell, S. (1990). Playing by the book: The problem of textbook knowledge. Journal of Educational Thought, 24(3A), 110-113

de Castell, S., Luke, A., \& Luke, C. (Eds.). (1989). Language, authority and criticism. London: Falmer Press.

Doyle, W. (1992). Curriculum and pedagogy. In P. Jackson (Ed.), Handbook of research on curriculum (pp. 486-516). New York: Macmillan. 
Duff, P., \& Uchida, Y. (1997). The negotiation of teachers' sociocultural identities and practices in postsecondary EFL classrooms. TESOL Quarterly, 31, 451-486

Employment and Immigration Canada. (1991). Canada, a sourcebook for orientation, language and settlement workers. Ottawa: Author.

Engkent, L., \& Bardy, K. (1992). Take part: Speaking Canadian English. Scarborough, ON: Prentice-Hall.

Fairclough, N. (1989). Language and power. London: Longman.

Fairclough, N. (1995). Critical discourse analysis. London: Longman

Freire, P., \& Macedo, D. (1995). A dialogue: Culture, language, and race. Harvard Educational Review, 65, 377-402.

Foucault, M. (1972). The archaeology of knowledge (Smith et al., Trans.). London: Tavistock.

Foucault, M. (1980). Power/knowledge: Selected interviews and other writings (Gordon et al., Trans.). New York: Pantheon.

Geertz, C. (1973). The interpretation of cultures. New York: Basic Books.

Grady, K. (1997). Critically reading an ESL text. TESOL Journal, 6(4), 7-10.

Hall, S. (1988). The toad in the garden: Thatcherism among the tourists. In C. Nelson \& L. Grossberg (Eds.), Marxism and the interpretation of culture. Urbana, IL: University of Illinois Press.

Hutchinson, T., \& Torres, E. (1994). The textbook as agent of change. ELT Journal, 48, 315-328.

Ilieva, R. (1997). Conceptualizations of culture, culture teaching, and culture exploration in second language education. Unpublished master's thesis, Simon Fraser University.

Keesing, R. (1994). Theories of culture revisited. In R. Borofsky (Ed.), Assessing cultural anthropology (pp. 301-310). New York: McGraw-Hill.

Kramsch, C. (1988). The cultural discourse of foreign language textbooks. In A. Singerman (Ed.), Touard a new integration of language and culture. Northeast conference reports (pp. 63-88). Middlebury: Northeast Conference.

Kramsch, C. (1993a). Context and culture in language teaching. Oxford: Oxford University Press.

Kramsch, C. (1993b). Language study as border study: experiencing difference. European Journal of Education, 28, 349-358.

Kress, G. (1989). Linguistic processes in sociocultural practices. Oxford: Oxford University Press.

Kroeber, A., \& Kluckhohn, C. (1952). Culture. A critical review of concepts and definitions (vol. 47). Cambridge, MA: Harvard University Press.

Lorimer, R. (1984). The nation in the schools: Wanted a Canadian education. Toronto, ON: OISE Press.

Luke, A. (1995). Text and discourse in education: an introduction to critical discourse analysis. Review of Research in Education, 21, 3-48.

Luke, A. (1988). Literacy, textbooks, and ideology. London: Falmer Press.

Manicom, A. (1987). Ideology and multicultural curriculum: Deconstructing elementary school texts. In J. Young (Ed.), Breaking the mosaic (pp. 75-103). Toronto, ON: Garamond Press.

Marcus, G., \& Fischer, M. (1986). Anthropology as cultural critique. Chicago, IL: University of Chicago Press.

McCarthy, C. (1998). The uses of culture. New York: Routledge.

Morgan, B. (1997). Identity and intonation: Linking dynamic processes in an ESL Classroom. TESOL Quarterly, 31, 431-450.

Norton, B. (1995a). Social identity, investment, and language learning. TESOL Quarterly, 29, 9-31.

Norton, B. (1995b). The theory of methodology in qualitative research. TESOL Quarterly, 29, 569-576.

Norton, B. (1997). Critical discourse research. In N. Hornberger (Ed.), The encyclopedia of language and education. Volume 8, Research methods in language and education (pp. 207-216). Dordrecht: Kluwer. 
Podoliak, E. (Ed.). (1988). Canadian ESL materials. TESL Talk, 19(1) (special issue). Toronto, ON: Ontario Ministry of Citizenship.

Pennycook, A. (1994). Incommensurable discourses? Applied Linguistics, 15, 115-138.

Pennycook, A. (1995). English in the world/The world in English. In J.W. Tollefson (Ed.), Potwer and inequality in language education (pp. 34-58). Cambridge, MA: Cambridge University Press.

Rosaldo, R. (1993). Culture and truth: The remaking of social analysis. Boston, MA: Beacon Press.

Street, B. (1993). Culture is a verb: Anthropological aspects of language and cultural process. In D. Graddol, L. Thompson, \& M. Byram (Eds.), Language and culture (pp. 23-43). Clevedon, UK: BAAL and Multilingual Matters.

Talbot, M. (1992). The construction of gender in a teenage magazine. In N. Fairclough (Ed.), Critical language azvareness (pp. 174-199). London: Longman.

Venezky, R. (1992). Textbooks in school and society. In P. Jackson (Ed.), Handbook of research on curriculum (pp. 436-461). New York: Macmillan. 